\title{
RAB12 Gene
}

National Cancer Institute

\section{Source}

National Cancer Institute. RAB12 Gene. NCI Thesaurus. Code C142754.

This gene is involved in intracellular membrane and protein trafficking. 